\title{
Interference of Azide with Cysteine Biosynthesis in Salmonella typhimurium
}

\author{
By MARCIN FILUTOWICZ, ZYGMUNT CIEŚLA AND \\ TADEUSZ KŁOPOTOWSKI \\ Institute of Biochemistry and Biophysics, Polish Academy of Sciences, \\ ul. Rakowiecka 36, 02-532 Warszawa, Poland
}

(Received 18 September 1978)

\begin{abstract}
The growth inhibition of Salmonella typhimurium aziA mutants by sodium azide is reversed by cystine and related compounds. NADPH-sulphite reductase (hydrogen-sulphide: NADP ${ }^{+}$ oxidoreductase; EC 1.8.1.2), an enzyme of cysteine biosynthesis, is inhibited in cell extracts by sodium azide. AziB mutants which are able to grow in the presence of the inhibitor without cystine were isolated. About half of them were mapped in the cys $K$ gene and have only residual activity of its product, $O$-acetylserine sulphydrylase A [ $O$-acetyl-Lserine acetate-lyase (adding hydrogen-sulphide); EC 4.2.99.8]. Sensitivity of wild type and azi $A$ mutants to azide was also reversed by a constitutive mutation in $c y s B$, the regulatory gene of cysteine biosynthesis. $C y s K$ and $c y s B$ mutants showed cross-resistance to azide and 1,2,4-triazole. It is suggested that the resistance of these mutants to azide is due to an increased activity of NADPH-sulphite reductase.
\end{abstract}

\section{INTRODUCTION}

The addition of azide to cultures of Salmonella typhimurium or Escherichia coli results in inhibition of their growth. Mutants resistant to azide bear mutations in the azi locus which is closely linked to the leu operon, both in E. coli (Yura \& Wada, 1968) and in S. typhimurium where the gene has been designated aziA (Cieśla et al., 1972). The function of the azi gene product is unknown.

The expression of resistance resulting from aziA mutations in S. typhimurium was found to depend on the composition of the medium. The aziA mutants were able to grow in the presence of azide only in rich media or in minimal medium supplemented with cystine.

In this paper we report the isolation of $S$ typhimurium mutants able to grow in the presence of azide without cystine or related compounds. Evidence is presented that azide inhibits NADPH-sulphite reductase, an enzyme of cysteine biosynthesis, and that mutations in the $c y s K$ or $\operatorname{cys} B$ genes suppress the inhibitory effect of azide on cysteine biosynthesis.

\section{METHODS}

Chemicals. $O$-Acetylserine was synthesized by the method of Sakami \& Toennies (1942) and kindly provided by Dr M. D. Hulanicka. All other chemicals were products of Sigma, except for L-djenkolic acid purchased from Calbiochem and carrier-free $\mathrm{Na}_{2}{ }^{35} \mathrm{SO}_{4}$ obtained from IBJ, Swierk, Poland.

Media. Medium C of Vogel \& Bonner (1956) supplemented with $0.5 \%$ (w/v) glucose was used routinely. In some experiments minimal $\mathrm{BS}$ medium was used. This was identical to medium $\mathrm{C}$ except that it contained an equimolar amount of $\mathrm{MgCl}_{2}$ instead of $\mathrm{MgSO}_{4}$. Minimal media for auxotrophs were supplemented with $\mathrm{L}$ amino acids $\left(40 \mu \mathrm{g} \mathrm{ml}^{-1}\right)$, thiamin $\left(4 \mu \mathrm{g} \mathrm{ml}^{-1}\right)$ and adenine $\left(80 \mu \mathrm{g} \mathrm{ml}^{-1}\right)$. The rich medium used was $1 \%(\mathrm{w} / \mathrm{v})$ nutrient broth (Difco) with $0.5 \%(\mathrm{w} / \mathrm{v}) \mathrm{NaCl}$. Solid media contained $1.5 \%(\mathrm{w} / \mathrm{v}$ ) agar (Oxoid). 
The final concentration of sodium azide in standard liquid and solid media was $3 \mathrm{~mm}$ and that of $1,2,4-$ triazole was $10 \mathrm{~mm}$.

Bacteria. The strains used were derivatives of Salmonella typhimurium LT2 (Table 1).

Genetic techniques. Transduction was performed directly on plates according to the procedure of Loper et al. (1964), using the int 4 mutant of phage P22 (Smith \& Levine, 1967).

The aziA mutants were isolated on minimal or nutrient broth solid media supplemented with 3 mMsodium azide. If minimal medium was used, it was supplemented with $0.5 \mathrm{~mm}$-cystine. A few drops of fresh nutrient broth culture (usually $0.25 \mathrm{ml}$ ) were spread over the agar plates. After 1 to $4 \mathrm{~d}$ incubation at $37^{\circ} \mathrm{C}$, colonies which had appeared were isolated and the resistant clones were purified by single-colony re-isolations on nutrient broth plates. Phage grown on the resistant mutants was used to transduce a leu recipient to verify that the mutation was in the aziA gene.

Measurement of ${ }^{35} \mathrm{SO}_{4}{ }^{2-}$ uptake. Bacteria were grown in BS medium supplemented with 1 mm-djenkolic acid. Exponentially growing bacteria were collected by centrifugation at room temperature, washed twice with BS medium and resuspended in the same medium supplemented with chloramphenicol $\left(50 \mu \mathrm{g} \mathrm{ml}^{-1}\right)$ and $1 \%(\mathrm{w} / \mathrm{v})$ glucose, to a density of $200 \mu \mathrm{g}$ dry wt $\mathrm{ml}^{-1}$. The reaction was started by adding $\mathrm{Na}_{2}{ }^{35} \mathrm{SO}_{4}$ $(10 \mu \mathrm{Ci} ; 5 \mathrm{nM})$ to $2 \mathrm{ml}$ bacterial suspension. After 1 to $5 \mathrm{~min}$ incubation at room temperature, samples were taken and filtered through nitrocellulose filters (Selectron, pore size $0.45 \mu \mathrm{m}$ ) which were subsequently washed with a solution containing $0.6 \%(\mathrm{w} / \mathrm{v}) \mathrm{NaCl}$ and $5 \mathrm{mM}-\mathrm{Na}_{2} \mathrm{SO}_{4}$. The filters were dried and radioactivity was measured in a toluene scintilation mixture.

Measurement of bacterial growth. Growth in liquid cultures at $37^{\circ} \mathrm{C}$ was followed turbidimetrically at $650 \mathrm{~nm}$ with a Varian-Techtron 650 spectrophotometer. An absorbance of 0.5 was equivalent to $210 \mu \mathrm{g}$ dry wt bacteria $\mathrm{ml}^{-1}$. The absorbance increased linearly with cell density up to $0 \cdot 8$. In some experiments, growth was followed at the same wavelength with a Spekol photometer. In this case, a transmission of $50 \%$ was equivalent to $202 \mu \mathrm{g}$ dry wt bacteria $\mathrm{ml}^{-1}$. The transmission values were converted to cell density using a calibration curve. The bacterial growth on solid minimal media was examined after $24 \mathrm{~h}$, or after $48 \mathrm{~h}$ if the minimal medium contained azide.

Preparation of cell extracts. Bacteria growing exponentially in $200 \mathrm{ml}$ minimal medium C supplemented with $1 \%(\mathrm{w} / \mathrm{v})$ glucose were harvested at $4{ }^{\circ} \mathrm{C}$ by centrifugation. They were washed three times with cold

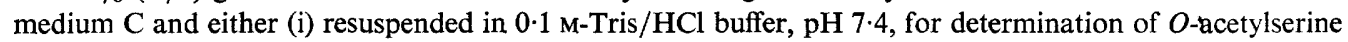
sulphydrylase [O-acetyl-L-serine acetate-lyase (adding hydrogen-sulphide); EC 4.2.99.8] and L-serine acetyltransferase [acetyl-CoA:L-serine $O$-acetyltransferase; EC 2.3 .1 .30 ], or (ii) resuspended in $0.05 \mathrm{M}$ potassium phosphate buffer, $\mathrm{pH} 7 \cdot 9$, for the determination of NADPH-sulphite reductase [hydrogensulphide: NADP ${ }^{+}$oxidoreductase; EC 1.8.1.2]. The suspensions were treated in an MSE ultrasonic disintegrator $(3 \times 30 \mathrm{~s})$ and then centrifuged at $12000 \mathrm{~g}$ for $40 \mathrm{~min}$. All enzyme activities were determined in the supernatant fractions after passage through a Sephadex G-50 column equilibrated with $\mathrm{Tris} / \mathrm{HCl}$ or potassium phosphate buffer, depending on the enzyme to be assayed.

Enzyme assays. $O$-Acetylserine sulphydrylase and serine acetyltransferase activities were determined as described by Kredich et al. (1969). NADPH-sulphite reductase was assayed according to Siegel \& Kamin (1971 a). One enzyme unit is defined as the amount catalysing the formation of $1 \mu \mathrm{mol}$ product $\mathrm{min}^{-1}$ or, for NADPH-sulphite reductase, the oxidation of $1 \mu \mathrm{mol} \mathrm{NADPH} \mathrm{min}^{-\mathbf{1}}$.

Protein determination. Protein was determined by the biuret method (Gornall et al., 1949) with bovine albumin as standard.

\section{RESULTS}

\section{Sensitivity of aziA mutants to sodium azide}

AziA mutants of S. typhimurium isolated on rich media containing 3 mm-azide were unable to grow on glucose minimal media supplemented with the same concentration of the inhibitor. These results indicated that the rich medium contained a component essential for growth and that the synthesis of this component was limited in the presence of azide.

In an attempt to identify this component, aziA mutants were replica-plated on to glucose minimal media supplemented with $3 \mathrm{~mm}$-azide and various amino acids. The presence of serine, cystine or methionine enabled aziA mutants, but not azi $A^{+}$strains, to overcome the inhibitory action of azide, indicating that azide may interfere with serine, cysteine or methionine biosynthesis. We therefore tested various intermediates of cysteine and methionine biosynthesis for the ability to reverse the inhibitory effect of azide in liquid minimal glucose medium. All the compounds tested (Table 2) increased the growth rate of TK1287 (aziA302) in medium containing azide. The most effective was $O$-acetylserine 
Table 1. Strains of Salmonella typhimurium LT2

\begin{tabular}{ll} 
Strain & \multicolumn{1}{c}{ Genotype } \\
TK340 & cysB1352 \\
TK1000 & Wild type LT2 strain \\
TK1208 & Wild type \\
TK1213 & aziA302 cysK2290 purA58 \\
TK1214 & aziA302 cysK2291 purA58 \\
TK1216 & cysB1352 \\
TK1219 & aziA311 cysA20 \\
TK1220 & aziA302 cysK2293 purA58 \\
TK1287 & aziA302 purA58 \\
TK1411 & trpC109 \\
TK1470 & cysA20 \\
TK1476 & cysCD519 \\
TK1514 & cysG382 \\
TK1538 & purA58 \\
TK1934 & aziA311 \\
TK1935 & aziA311 cysK2291 \\
TK1936 & aziA311 cysK2290 \\
&
\end{tabular}

Source or derivation

N. M. Kredich

N. D. Zinder via B. N. Ames

By transduction of Trp ${ }^{+}$from TK340 to TK1411

As AziB mutant of TK1287

As AziB mutant of TK1287

By transduction of $\mathrm{Trp}^{+} \mathrm{Cys}^{-}$from TK340 to TK1411

As AziA mutant of TK1470

As 1,2,4-triazole-resistant mutant of TK1287

As AziA mutant of TK1538

P. E. Hartman

A. B. Pardee

K. E. Sanderson

K. E. Sanderson

K. E. Sanderson

By transduction of $\mathrm{Cys}^{+}$from TK1214 to TK1219

By transduction of $\mathrm{Cys}^{+} \mathrm{AziB}$ from TK1214 to TK1219

By transduction of $\mathrm{Cys}^{+} \mathrm{AziB}$ from TK1213 to TK1219

Table 2. Effect of intermediates of sulphur metabolism on the growth of an aziA mutant in the presence or absence of sodium azide

Strain TK1287 (aziA302 purA58) was grown in BS medium supplemented with 0.1 mM-sulphate and $1 \%(\mathrm{w} / \mathrm{v})$ glucose. After $12 \mathrm{~h}$, bacteria were collected, washed with warm BS medium and inoculated into BS medium supplemented with sulphate, glucose and the sulphur compound indicated. The cultures were grown to density of $10 \mu \mathrm{g}$ dry wt bacteria $\mathrm{ml}^{-1}$. Each culture was then divided: sodium azide ( $3 \mathrm{~mm}$ ) was added to one half and the other served as a control.

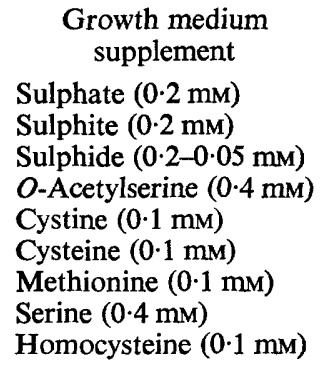

$\begin{array}{cc}\text { Doubling time (divisions } \mathrm{h}^{-1} \text { ) } \\ \text { Control } & +3 \text { mm-azide } \\ 1.00 & 0.10 \\ 1.00 & 0.25 \\ 1.00 & 0.40 \\ 1.03 & 0.75 \\ 1.00 & 0.50 \\ 0.85 & 0.20 \\ 1.09 & 0.25 \\ 1.00 & 0.33 \\ 1.08 & 0.33\end{array}$

followed by cystine and sulphide. The effects of serine, homocysteine, sulphite, methionine and cysteine were less pronounced. These results supported the suggestion that inhibition of growth of the aziA mutants was due to interference of azide with sulphur metabolism. The relatively weak effect of cysteine could be due to its toxic effect on $S$. typhimurium (unpublished observation). The weak effect of methionine in comparison with cystine suggested that the direct target of azide action is cysteine biosynthesis. The partial reversion of growth inhibition by methionine may be due to a sparing effect on the cysteine pool. A similar effect of methionine has been observed in bradytrophic cys mutants (Quereshi et al., 1975). 


\section{Lack of sodium azide effect on sulphate transport}

Active transport of various substances is inhibited by azide (Harold, 1972). Thus, if the transport of sulphate into the cells is reduced in the presence of azide, this could be the primary reason for the shortage of sulphur-containing amino acids. To investigate the possible effect of azide on sulphate transport, we determined the uptake of ${ }^{35} \mathrm{SO}_{4}{ }^{2-}$ in the presence or absence of azide by strains TK1000 (Cys $\left.{ }^{+}\right)$, TK1476 (cysCD519) and TK1514 (cysG382). The cysCD519 mutant is devoid of sulphate-activating enzymes (Dreyfuss \& Monty, 1963) and the cysG382 mutant is devoid of the haem component of NADPHsulphite reductase (Siegel \& Kamin, $1971 b$ ). Thus, in the deletion mutant cysCD519, the metabolism of sulphate transported into cells is completely prevented and any accumulation of radioactivity represents only the transport process. The data of Table 3 show that azide did not alter the rate of ${ }^{35} \mathrm{SO}_{4}{ }^{2-}$ uptake. Mutant cysG382 can metabolize sulphate up to the stage of sulphite, but, again, the uptake of sulphate was not reduced by 5 mm-azide (Table 3 ). The fact that the rate of accumulation of radioactivity by wild-type bacteria was reduced by $60 \%$ in the presence of azide indicates that it is the metabolism of sulphate and not its transport that is inhibited by azide. Thus, it seems unlikely that the azide-sensitive step in cysteine biosynthesis precedes formation of sulphite.

\section{Inhibitory effect of azide on the activity of $N A D P H$-sulphite reductase}

The activity of NADPH-sulphite reductase in yeast (Yoshimoto \& Sato, 1968) and in $E$. coli (Siegel et al., 1974) is inhibited by compounds such as cyanide, carbon monoxide or arsenite which block the respiratory chain. The affinity of these inhibitors for sirohaem, the prosthetic group of the enzyme, is responsible for the effect (Murphy \& Siegel, 1973). Since azide, being an inhibitor of catalase (Schonbaum \& Chance, 1976), may also have an affinity for the haem group, we investigated the possibility that it may interfere with the activity of NADPH-sulphite reductase.

A characteristic feature of this enzyme is its broad substrate specificity; in addition to the natural substrate, it is also able to reduce hydroxylamine and nitrite (Siegel et al., 1974). Lineweaver-Burk plots for experiments with sulphite and hydroxylamine (Fig. 1) indicated that azide inhibited the reduction of both substrates. Since the crossing points of the lines did not fall on either of the axes, the azide inhibition apparently was not completely competitive with either sulphite or hydroxylamine. Alternatively, both substrates could be reduced by two distinct enzymes, only one of which was sensitive to azide. The same results were obtained in other experiments in which NADPH-sulphite reductase activity was measured in the presence of different concentrations of azide with a constant concentration of sulphite or hydroxylamine (Dixon plot). Again, the inhibitory effect of azide was observed with both substrates (data not shown). Substrate and azide affinity constants were calculated from Fig. 1 and from the Dixon plot (data not shown): $K_{\mathrm{m}}$ values for sulphite and hydroxylamine were $10 \mu \mathrm{M}$ and $8.3 \mathrm{~mm}$, respectively, and the $K_{\mathrm{i}}$ value for azide was $2.5 \mathrm{~mm}$. Comparison of these values indicates that the affinity of azide for NADPH-sulphite reductase is intermediate between those of sulphite and hydroxylamine.

\section{Isolation of mutants resistant to sodium azide on minimal media}

When attempts were made to isolate azide-resistant mutants on azide minimal plates, none or very few were obtained. All of these proved to be double mutants carrying, in addition to azi $A$, a mutation unlinked to the leu operon. In contrast, mutants able to grow on azide minimal media appeared with high frequency if aziA strains were used for the selection. The phenotype of the mutants which could grow in the presence of azide on minimal media with sulphate as sole sulphur source was designated AziB.

The inhibition of growth of $S$. typhimurium by 1,2,4-triazole is mediated through an effect on cysteine biosynthesis (Hulanicka \& Kłopotowski, 1972; Hulanicka et al., 1972). 
Table 3. Effect of sodium azide on uptake of sulphate

Uptake of ${ }^{35} \mathrm{SO}_{4}{ }^{2-}$ by bacteria was measured after 1 and $5 \mathrm{~min}$ incubation (see Methods). The results given are the average values of three independent assays.

$\begin{array}{clccc}\text { Strain } & \begin{array}{l}\text { Relevant } \\ \text { genotype }\end{array} & \overbrace{\text { Control }}^{\text {Uptake of sulphate }} & +5 \text { mM-azide } & \begin{array}{c}\text { \% of } \\ \text { control }\end{array} \\ \text { TK1000 } & \text { Wild type } & 300 & 120 & 40 \\ \text { TK1476 } & \text { cysCD519 } & 182 & 181 & 99 \\ \text { TK1514 } & \text { cysG382 } & 34 & 43 & 126\end{array}$

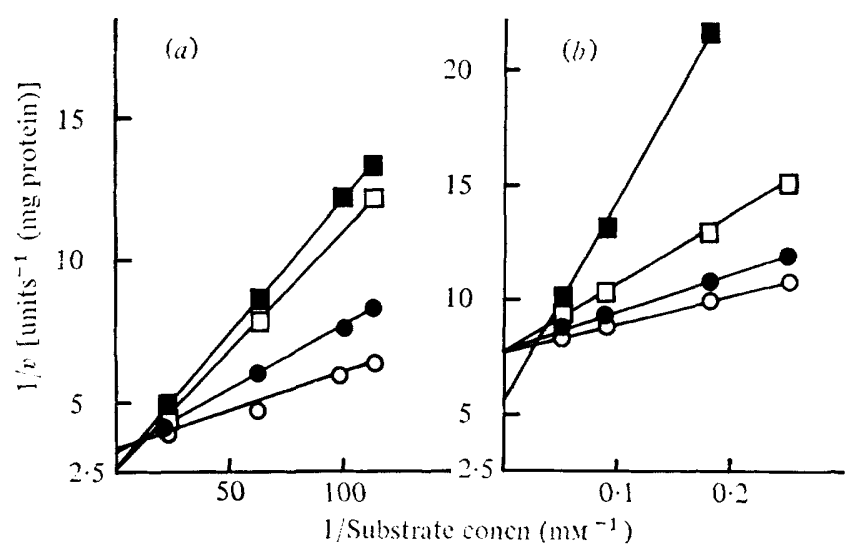

Fig. 1. Effect of sodium azide on NADPH-sulphite reductase with sulphite $(a)$ or hydroxylamine (b) as substrate. Cell extracts were used as the source of enzyme. The data are presented as Lineweaver-Burk double-reciprocal plots for the initial rate of NADPH oxidation measured by the change in $A_{340}$. (a) With $\mathrm{NaHSO}_{3}$ as substrate: $\mathrm{O}$, control; $\bullet$, plus 2 mM-azide; $\square$, plus 4 mmazide; $\mathbf{\square}$, plus 5 mm-azide. (b) With $\mathrm{NH}_{2} \mathrm{OH}$ as substrate: $\bigcirc$, control; $\bullet$, plus 1 mm-azide; $\square$, plus 3 mM-azide; $\boldsymbol{\square}$, plus 5 mM-azide.

Mutants resistant to 1,2,4-triazole have lesions in the cys $K$ locus which is about $50 \%$ cotransduced by $\mathrm{P} 22$ with $c y s A$ and codes for $O$-acetylserine sulphydrylase A (Hulanicka et al., 1974).

It was possible that some of the AziB mutants might show cross-resistance to azide and 1,2,4-triazole. When tested, about half of the AziB strains were able to grow on minimal medium plates containing $10 \mathrm{~mm}-1,2,4$-triazole. To characterize them genetically, phage lysates from two such mutants (TK1213 and TK1214) and from the control strain TK1220, isolated as resistant to 1,2,4-triazole, were used to transduce TK1219 (cysA20 aziA311) to prototrophy (Table 4). The AziB phenotype was recovered in about $60 \%$ of the Cys ${ }^{+}$ recombinants from crosses with strains TK1213 and TK1214 as donors, and a similar percentage of $\mathrm{Cys}^{+} \mathrm{AziB}$ recombinants was obtained in the cross with TK1220 as donor. We concluded that the three strains were mutated in the $c y s K$ gene and assigned the allele numbers cysK2290, cysK 2291 and cysK 2293 to their mutations.

The cross-resistance of one of these transductants to azide and 1,2,4-triazole is shown in Fig. 2. Strain TK1934 (aziA311) was able to grow in the presence of azide or 1,2,4-triazole only if the medium was supplemented with cystine, whereas the growth of strain TK1935 (aziA311 cysK2291) was not inhibited by 1,2,4-triazole, regardless of whether cystine was present. The latter strain grew quite well in the presence of azide without cystine, the growth rate being only $40 \%$ slower than that in the absence of azide. This result is consistent with the notion that the AziB phenotype is due to mutations in the cys $K$ gene. 
Table 4. Linkage of AziB markers to the cysA locus

In all crosses, strain TK1219 (cysA20 aziA311) was used as recipient. Cys ${ }^{+}$prototrophic recombinants were selected on glucose minimal plates supplemented with adenine. The recombinants were picked on to nutrient broth plates and after $12 \mathrm{~h}$ were replica-plated on to minimal ager plates supplemented with 3 mM-azide to score the AziB phenotype.

$\begin{array}{ccccc}\begin{array}{c}\text { Donor } \\ \text { strain }\end{array} & \begin{array}{c}\text { Relevant } \\ \text { genotype }\end{array} & \begin{array}{c}\text { No. of } \\ \text { recombinants } \\ \text { scored }\end{array} & \begin{array}{c}\text { No. of } \\ \text { Cys } \\ \text { recombinants }\end{array} & \begin{array}{c}\text { Linkage } \\ (\%)\end{array} \\ \text { TK1213 } & \text { cysK2290 } & 208 & 133 & 64 \\ \text { TK1214 } & \text { cysK2291 } & 384 & 236 & 61 \\ \text { TK1220 } & \text { cysK2293 } & 104 & 66 & 63\end{array}$

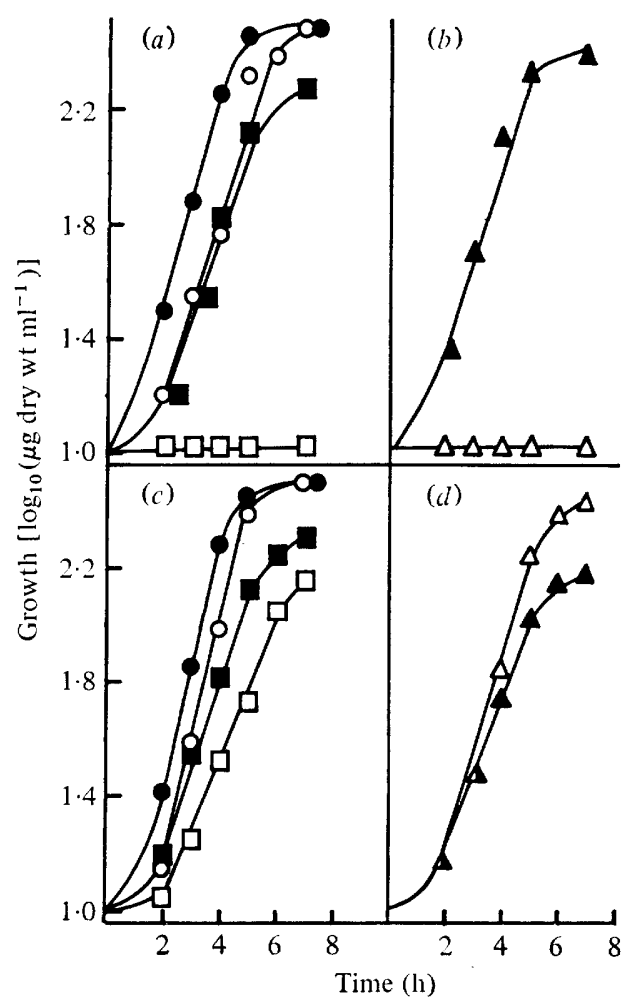

Fig. 2. Growth curves of $(a, b)$ strain TK1934 (aziA311) and (c,d) strain TK1935 (aziA311 cysK2291). Cultures were grown in minimal medium $C$ with $1 \%(\mathrm{w} / \mathrm{v})$ glucose: $O$, control; $\bullet$, plus $0.5 \mathrm{~mm}$ cystine; $\square$, plus $2 \mathrm{~mm}$-azide; $\square$, plus $2 \mathrm{~mm}$-azide and $0.5 \mathrm{~mm}$-cystine; $\Delta$, plus $10 \mathrm{~mm}-1,2,4$-triazole; $\boldsymbol{A}$, plus $10 \mathrm{~mm}-1,2,4$-triazole and $0.5 \mathrm{~mm}$-cystine. Cystine was added as described by Kredich (1971).

\section{Cross-resistance of a cysB mutant to sodium azide and 1,2,4-triazole}

The $c y s B$ gene product has a regulatory function in cysteine biosynthesis(Jones-Mortimer, $1968 a, b$; Spencer et $a l ., 1967)$. Most $c y s B$ mutants, including those with the gene deleted, are cysteine auxotrophs. Mutant TK1216 (cysB1352) represents a class of constitutive mutants in which synthesis of the enzymes of the cysteine pathway does not require the inducer, $O$-acetylserine, and is not repressed by cystine (Kredich, 1971). This mutant is resistant to 1,2,4-triazole and selenate (Hulanicka \& Kłopotowski, 1972).

We examined the sensitivity of the two isogenic strains TK1208 (cys ${ }^{+}$azi $\left.A^{+}\right)$and TK1216 (cysB1352 azi $\mathrm{A}^{+}$) to $1 \mathrm{~mm}$-azide and $10 \mathrm{~mm}-1,2,4$-triazole (Fig. 3). The doubling time of 


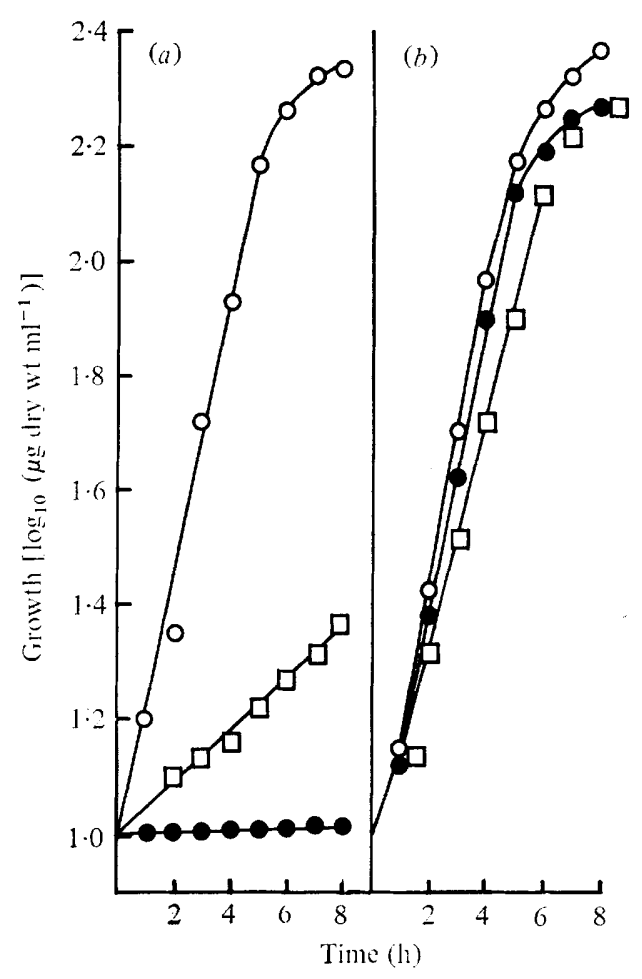

Fig. 3. Growth curves of (a) strain TK1208 $\left(a z i^{+}\right)$and (b) strain TK1216 (azi+ cysB1352). Cultures were grown in minimal medium $C$ with $1 \%(\mathrm{w} / \mathrm{v})$ glucose: $O$, control; $O$, plus $10 \mathrm{~mm}-1,2,4-$ triazole; $\square$, plus $1 \mathrm{~mm}$-azide.

TK1208 in the presence of azide was more than five times that in its absence, and this strain was unable to grow in presence of 1,2,4-triazole. In contrast, strain TK1216 grew well in the presence of azide or 1,2,4-triazole. These results suggest that growth inhibition in minimal media supplemented with azide is due to cysteine deficiency even in the presence of the azi $A^{+}$gene product. The results also indicate that not only cysK strains but also the constitutive $c y s B$ mutant show cross-resistance to azide and 1,2,4-triazole.

\section{Activity of the enzymes of cysteine biosynthesis in AziB mutants}

To characterize in more detail the properties of AziB mutants, the activities of $O$-acetylserine sulphydrylase, NADPH-sulphite reductase and serine acetyltransferase were determined in extracts of TK1934 (aziA311), TK1935 (aziA311 cysK2291) and TK1936 (aziA311 cysK2290) (Table 5). The activity of $O$-acetylserine sulphydrylase was decreased, compared with the control strain, to 23 and $12 \%$ in the cys $K 2290$ and cys $K 2291$ mutants, respectively. These results confirm the deduction from genetic analysis of the mutants and prove their identity as cys $K$ mutants. An important feature of $c y s K$ mutants is their increased activity of NADPH-sulphite reductase, the enzyme which is inhibited by azide. Similar increases of the enzyme activity in cys $K$ strains have been observed by Hulanicka \& Kłopotowski (1972) in S. typhimurium and, more recently, by Fimmel \& Loughlin (1977) in E. coli.

\section{DISCUSSION}

We have found that NADPH-sulphite reductase, an enzyme of cysteine biosynthesis (see Fig. 4), is inhibited in cell extracts of $S$. typhimurium by sodium azide. The inhibition accounts for one of several inhibitory effects on growth of the bacterium. It can be prevented 
Table 5. Activity of cysteine biosynthesis enzymes in AziB strains of S. typhimurium

Cell extracts were prepared from bacteria grown in medium $\mathrm{C}$ supplemented with $1 \%(\mathrm{w} / \mathrm{v})$ glucose and sulphate as the sole source of sulphur. Enzyme activities are expressed as units (mg protein $)^{-1}$ and, in parentheses, as a percentage of the enzyme activity in strain TK1934.

$\begin{array}{clccc}\text { Strain } & \begin{array}{c}\text { Relevant } \\ \text { genotype }\end{array} & \begin{array}{c}\text { O-Acetyl- } \\ \text { serine } \\ \text { sulphydrylase }\end{array} & \begin{array}{c}\text { NADPH- } \\ \text { sulphite } \\ \text { reductase }\end{array} & \begin{array}{c}\text { Serine } \\ \text { acetyl- } \\ \text { transferase }\end{array} \\ \text { TK1934 } & \text { aziA311 } & 4 \cdot 60(100) & 0.078(100) & 0 \cdot 048(100) \\ \text { TK1935 } & \text { aziA311 cysK2291 } & 0.56(12) & 0 \cdot 180(230) & 0 \cdot 044(91) \\ \text { TK1936 } & \text { aziA311 cysK2290 } & 1.06(23) & 0.118(151) & 0 \cdot 029(60)\end{array}$

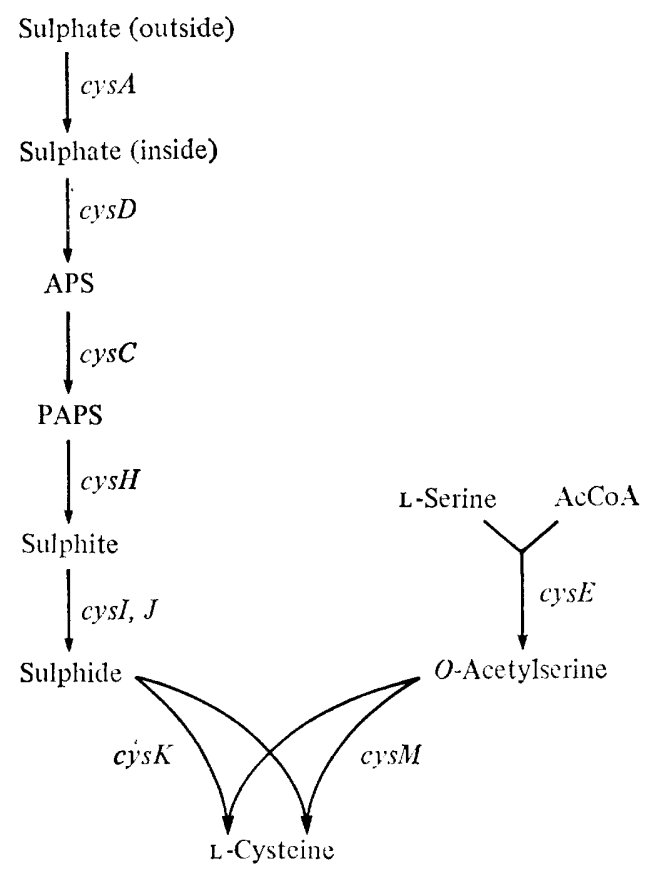

Fig. 4. The pathway of L-cysteine biosynthesis in S. typhimurium (APS, adenosine 5'-phosphosulphate; PAPS, 3'-phosphoadenosine 5'-phosphosulphate). The consecutive reactions of the sulphur assimilation branch of the pathway are catalysed by the following enzymes (corresponding structural genes are given in parentheses): sulphate permease (cys $A$ ), ATP sulphurylase (cys $D$ ), APS kinase $(c y s C)$, PAPS reductase $(c y s H)$, NADPH-sulphite reductase (cys $I$ and $c y s J)$ and the last reaction by both $O$-acetylserine sulphydrylase A $(c y s K)$ and $O$-acetylserine sulphydrylase B $(\operatorname{cys} M)$. Synthesis of these enzymes is inducible by $O$-acetylserine, repressible by L-cysteine or $L$-cystine and requires the product of the cys $B$ regulatory gene. The only reaction of the carbon branch of the pathway is catalysed by L-serine acetyltransferase ( $c y s E$ ). Synthesis of this enzyme is apparently constitutive as its specific activity is not affected by $c y s B$ mutations, $O$-acetylserine or L-cysteine. Feedback inhibition by L-cysteine is exerted on sulphate permease and L-serine acetyltransferase.

by adding cystine or some related compounds to the growth medium. The effectiveness of compounds other than cystine in preventing the inhibitory effect of azide on the growth of aziA mutants can be explained by different mechanisms. The effect of sulphide, which is the product of the sensitive enzyme, is obvious. Since sulphite and azide behave competitively in their interaction with the enzyme, exogenous sulphite supply counteracts the inhibitory effect of azide. For each molecule of methionine synthesized, one molecule of cysteine is used, and so the cell demand for cysteine is alleviated by feed-back inhibition exerted by added methionine on the first enzyme of its biosynthesis (Smith, 1971), which results in 
its sparing effect on the cysteine requirement. Addition of homocysteine, a precursor of methionine, could lead to the same sparing effect. The effect of $O$-acetylserine may be due to its ability to induce of all enzymes of the cysteine biosynthetic pathway (Kredich, 1971; Hulanicka \& Kłopotowski, 1972). Presumably, exogenous serine increases the concentration of $O$-acetylserine within the cells.

The same compounds are effective in supporting growth of bradytrophic mutants with defective serine acetyltransferase and reverse the effect of 1,2,4-triazole, another inhibitor of cysteine biosynthesis (Hulanicka et al., 1972).

About half of the mutants isolated as resistant to azide map in the cys $K$ gene and have only residual activity of $O$-acetylserine sulphydrylase A. The resistance of $c y s K$ mutants to 1,2,4-triazole is due to the fact that $O$-acetylserine sulphydrylase A catalyses not only cysteine synthesis from $O$-acetylserine and sulphide, but also 1,2,4-triazolyl-1-alanine from 1,2,4-triazole and $O$-acetylserine: the latter reaction leads to $O$-acetylserine depletion in the bacteria and, in consequence, restricts induction of cysteine biosynthetic enzymes (Kredich et al., 1975). In the cysK mutants, the last step of cysteine biosynthesis is catalysed by $O$-acetylserine sulphydrylase B, coded by gene $\operatorname{cys} M$ (M. D. Hulanicka, personal communication). Apparently, the other sulphydrylase is not able to produce 1,2,4triazolyl-1-alanine. The presence of the distinct enzymes for the last step of cysteine biosynthesis explains both the prototrophy of cys $K$ mutants and their resistance to 1,2,4triazole.

We have demonstrated that our $c y s K$ mutants grown on sulphate as sulphur source have an increased activity of NADPH-sulphite reductase. Similar increased activities have been observed in cysK mutants of $S$. typhimurium (Hulanicka \& Kłopotowski, 1972) and $E$. coli (Fimmel \& Loughlin, 1977). Mutant cysB1352, in which the cysteine biosynthetic enzymes are not repressible by cystine, does not require $O$-acetylserine for their induction and displays increased activities of these enzymes (Kredich, 1971); it is resistant to 1,2,4triazole and also to $1 \mathrm{~mm}$-azide. In the presence of an aziA mutation its resistance to higher azide concentrations is similar to that of double aziA cysK mutants (data not shown). It thus seems likely that the increased NADPH-sulphite reductase activity may account for the azide resistance of cys $K$ mutants.

The increase in the activity of NADPH-sulphite reductase in S. typhimurium cysK and cys $B$ mutants was not more than threefold. Is this sufficient to ensure resistance to azide? In answering this question one should take into consideration that the growth of aziA mutants in the presence of azide and cystine or of aziA cys $K$ mutants in the absence of the amino acid was still slower than that of the mutants in unsupplemented medium. We presume that the effects of azide on other sensitive targets, like DNA biosynthesis (Cieśla et al., 1974), or its interference with energy metabolism limit the growth rate and, therefore, lower the requirement for cysteine.

Several targets of azide inhibitory effects are known. In energy metabolism it inhibits $\mathrm{Mg}^{2+}$-dependent membrane-bound ATPase in bacteria (Roisin \& Kepes, 1972; Kobayashi et al., 1977), in yeast (Kovač \& Istenesova, 1968) and in isolated animal mitochondria (Bogucka \& Wojtczak, 1966). Azide enhances the rate of proton diffusion across biological membranes and, in consequence, interferes with generation of the high energy membrane state (Harold, 1972). Moreover, azide inhibits the activity of cytochrome $c$ oxidase activity (Caughey et al., 1976).

Azide also acts on processes apparently unrelated to the main mechanisms of energy transformation. It inhibits another haem protein, catalase (Schonbaum \& Chance, 1976), and it inhibits bacterial DNA replication both in vivo and in toluene-treated cells (Cieśla et al., 1974). Azide is also a potent base-substitution type mutagen (Nilan et al., 1973; McCann et al., 1975).

The multiplicity of inhibitory effects of azide may be due either to its high activity or to the occurrence of similar targets in functionally unrelated enzymes. The latter alternative is 
suggested by the fact that three of the azide-sensitive enzymes - cytochrome $c$ oxidase, catalase and sulphite reductase - contain haem prosthetic groups.

Other relationships between apparently distinct targets of azide effects are also possible. We have found that cysteine prevents the mutagenic action of azide (unpublished results); it is also absent in a class of $c y s K$ mutants with defective $O$-acetylserine sulphydrylase. The relationship between cysteine biosynthesis and the mutagenic effect of azide is now under study.

We thank Dr M. D. Hulanicka for helpful discussions throughout this investigation, and Dr A. Paszewski for comments on the manuscript. This work was supported by the Polish Academy of Sciences within Project No. 09.7.

\section{REFERENCES}

Bogucka, K. \& WoJTCZaK, L. (1966). Effect of sodium azide on oxidation and phosphorylation processes in rat-liver mitochondria. Biochimica et biophysica acta 122, 381-392.

Caughey, W. S., Wallace, W. J., Volpe, J. A. \& YoshiKAWA, S. (1976). Cytochrome $c$ oxidase. In The Enzymes, vol. 13, pp. 299-361. Edited by P. D. Boyer. New York: Academic Press.

Cieśla, Z., Bagdasarian, M., Szczurkiewicz, W., PRZYGONSKA, M. \& KłOPOTOWSKI, T. (1972). Defective cell division in the thermosensitive mutants of Salmonella typhimurium. Molecular and General Genetics 116, 107-125.

Cieśla, Z., Mardarowicz, K. \& K£opotowski, T. (1974). Inhibition of DNA synthesis and cell division in Salmonella typhimurium by azide. Molecular and General Genetics 135, 339-348.

Dreyfuss, J. \& MoNTy, K. J. (1963). The biochemical characterization of cysteine-requiring mutants of Salmonella typhimurium. Journal of Biological Chemistry 238, 1019-1031.

Fimmel, A. L. \& Loughlin, R. E. (1977). Isolation and characterization of cysK mutants of Escherichia coli K12. Journal of General Microbiology 103, 37-43.

Gornall, A. G., Bardawill, D. J. \& David, M. M. (1949). Determination of serum proteins by means of the biuret reaction. Journal of Biological Chemistry 177, 751-766.

Harold, F. M. (1972). Conservation and transformation of energy by bacterial membranes. Bacteriological Reviews 36, 751-766.

Hưlanicka, M. D. \& KŁopotowski, T. (1972). Mutants of Salmonella typhimurium resistant to triazole. Acta biochimica polonica 19, 27-32.

Hulanicka, M. D., KŁopotowski, T. \& SMith, D. A. (1972). The effect of triazole on cysteine biosynthesis in Salmonella typhimurium. Journal of General Microbiology 72, 291-301.

Hưlanicka, M. D., KRedich, N. M. \& Treiman, D. M. (1974). The structural gene for $O$-acetylserine sulphydrylase A in Salmonella typhimurium: identity with TrzA locus. Journal of Biological Chemistry 249, 867-872.

JoNES-Mortimer, M. C. $(1968 a)$. Positive control of sulphate reduction in Escherichia coli. Isolation, characterization and mapping of cysteineless mutants of Escherichia coli K12. Biochemical Journal 110, 589-595.
Jones-Mortimer, M. C. $(1968 b)$. Positive control of sulphate reduction in Escherichia coli. The nature of the pleiotropic cysteineless mutants of Escherichia coli K12. Biochemical Journal 110, 597-602.

Kobayashi, H., MaEda, M. \& ANRAKU, Y. (1977). Membrane-bound adenosine triphosphatase of Escherichia coli. III. Effects of sodium azide on the enzyme functions. Journal of Biochemistry 81, 1071-1077.

Kovač, L. \& IsTENESOVA, B. (1968). Oxidative phosphorylation in yeast. I. Isolation and properties of phosphorylating mitochondria from stationary phase cells. Biochimica et biophysica acta 153, $32-42$.

KREDICH, N. M. (1971). Regulation of L-cysteine biosynthesis in Salmonella typhimurium. Effect of growth on varying sulfur source and $O$-acetylserine on gene expression. Journal of Biological Chemistry 246, 3474-3484.

KREDICH, N. M., BeCKer, M. A. \& Tomkins, G. M. (1969). Purification and characterization of cysteine synthetase, a bifunctional complex, from Salmonella typhimurium. Journal of Biological Chemistry 244, 2428-2439.

Kredich, N. M., FoOte, L. J. \& Hulanicka, M. D. (1975). Studies on the mechanism of inhibition of Salmonella typhimurium by $1,2,4$ triazole. Journal of Biological Chemistry 250, 7324-7329.

Loper, J. C., Grabnar, M., Stahl, R. C., Hartman, Z. \& Hartman, P. E. (1964). Genes and proteins involved in histidine biosynthesis of Salmonella typhimurium. Brookhaven Symposia in Biology 17, 15-53.

McCann, J., Choi, E., Yamasaki, E. \& Ames, B. N. (1975). Detection of carcinogens as mutagens in the Salmonella typhimurium microsome test: assay of 300 chemicals. Proceedings of the National Academy of Sciences of the United States of America 72, 5135-5139.

MURPhy, M. J. \& SiEgEL, L. M. (1973). Siroheme and sirohydrochlorin. Journal of Biological Chemistry 248, 6911-6919.

Nilan, R. A., Sideris, E. G., Kleinhofs, A., SANDER, C. \& KonzaK, C. F. (1973). Azide - a potent mutagen. Mutation Research 17, 142-144.

Quereshi, M. A., SMith, D. A. \& Kingsman, A. J. (1975). Mutants of Salmonella typhimurium responding to cysteine or methionine: their 
nature and possible role in the regulation of cysteine biosynthesis. Journal of General Microbiology 89, 358-370.

Rorsin, M. P. \& KePES, A. (1972). The membrane ATP-ase of Escherichia coli. I. Ion dependence and ADP-ATP exchange reaction. Biochimica et biophysica acta 275, 333-345.

SaKami, W. \& Toennies, G. (1942). The investigation of amino acid reactions by methods of non-aqueous titrimetry. II. Differential acetylation of hydroxy groups and a method for the preparation of the $O$-acetyl derivatives of hydroxy amino acids. Journal of Biological Chemistry 144, 203-217.

Schonbaum, G. R. \& Chance, B. (1976). Catalase. In The Enzymes, vol. 13, pp. 363-408. Edited by P. D. Boyer. New York: Academic Press.

Siegel, L. M. \& Kamin, H. (1971 a). TPNH-sulfite reductase (Escherichia coli). Methods in Enzymology 17B, 539-545.

Siegel, L. M. \& Kamin, H. (1971b). TPNH-sulfite reductase (SiR) from $E$. coli and Salmonella typhimurium: subunit structure and gene assignment. Federation Proceedings 30, 1261.

Siegel, L. M., Davis, P. S. \& Kamin, H. (1974). Reduced nicotinamide adenine dinucleotide phos- phate-sulfite reductase of enterobacteria. III. The Escherichia coli hemoflavoprotein: catalytic parameters and the sequence of electron flow. Journal of Biological Chemistry 249, 1572-1586.

SмттH, D. A. (1971). S-amino acids metabolism and its regulation in Escherichia coli and Salmonella typhimurium. Advances in Genetics 16, 141-165.

Smith, H. O. \& LeVINe, M. (1967). A phage P22 gene controlling integration of prophage. Virology 31, 207-216.

SPENCER, H. T., Collins, J. \& Monty, K. J. (1967). Sequential regulation of cysteine biosynthesis in Salmonella typhimurium. Federation Proceedings 26, 677.

Vogel, H. J. \& Bonner, D. M. (1956). Acetylornithinase of Escherichia coli: partial purification and some properties. Journal of Biological Chemistry 218, 97-106.

Yoshimoto, A. \& SATo, R. (1968). Studies on yeast sulfite reductase. I. Purification and characterization. Biochimica et biophysica acta 153, 555-575.

YuRA, Z. \& WADA, C. (1968). Phenethyl alcohol resistance in Escherichia coli. I. Resistance of strain $\mathrm{C} 600$ and its relation to azide-resistant strain. Genetics 59, 177-190. 